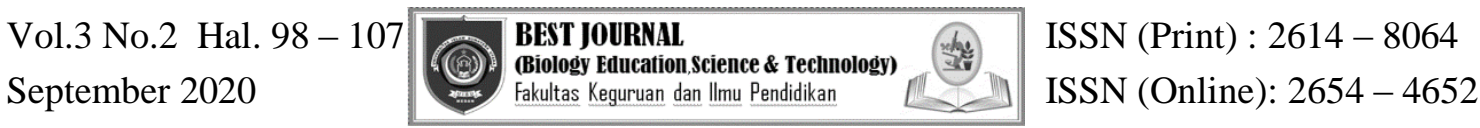

\title{
Kajian Bioaktivitas Senduduk (Melastoma malabathricum) dan Pemanfaatanya
}

\author{
Marina Silalahi \\ Prodi Pendidikan Biologi Fakultas Keguruan Dan Ilmu Pendidikan \\ Universitas Kristen Indonesia, Jakarta Timur \\ Marina.silalahi@uki.ac.id
}

\begin{abstract}
ABSTRAK
Melastoma malabathricum atau senduduk merupakan tumbuhan multifungsi yang digunakan sebagai hiasan, bahan pangan dan obat tradisional. Pemanfaatan tumbuhan sebagai obat tradisional berhubungan dengan kandungan metabolit sekundenya maupun bioaktivitasnya. Kajian ini bertujuan menjelaskan hubungan pemanfaatan M. malabathricum dan bioaktivitasnya. Penulisan artikel ini merupakan kajian literatur terhadap hasil penelitian tentang pemanfaatan dan bioaktivitas M. malabatricum yang terbit secara online. Beberapa kata kunci yang digunakan adalah M. malabathricum, uses of M. malabatrichum dan bioactivities of M. malabathricum. Secara etnobotani M. malabathricum digunakan untuk untuk mengatasi diare, patah tulang, luka, mengatasi kejengkolan, kejang, ayan dan sariawan. Bioactivitas M. malabatrhricum anatara lain anti kanker, hepatoprotektif, anti kolesterol, anti mikroba, antioksidan, antiulkus, analgesik dan antidiabetes mellitus. Biaktivitas M. malabathricum sebagai antimikroba dan antikanker sangat potensial dikembangkan sehingga dapat digunakan sebagai obat alternative gangguan saluran pencernaan dan kanker.
\end{abstract}

Kata Kunci : Melastoma malabathricum, anti mikroba, anti kanker

\begin{abstract}
Melastoma malabathricum is a multifunctional plant which used as ornament, food ingredients and traditional medicine. The utilization of medicinal plants as traditional medicine is related to the secondary metabolite content and its bioactivity. This study aims to explain the correlation of the use of M. malabathricum and its bioactivity. The writing of this article is a literature review of the results of research on the use and bioactivity of M. malabatricum published online. Some of the key words used are M. malabathricum, uses of $M$. malabatrichum and bioactivities of $M$. malabathricum. The ethnobotany study of M. malabathricum have been used to treat diarrhea, fractures, wounds, overcoming cramps, seizures, sores, and cancer. Bioactivity of $M$. malabathricum is anti-cancer, hepatoprotective, anti-cholesterol, anti-microbial, antioxidant, anti-ulcer, analgesic and anti-diabetes mellitus. The bioactivities of M. malabathricum as anti-microbial and anti-cancer is very potential to be developed so that it can be used as an alternative medicine for digestive tract disorders and cancer.
\end{abstract}

Keywords: Melastoma malabathricum, antimicrobial, anticancer 


\section{PENDAHULUAN}

\section{Latar Belakang}

Bahan alam dari tumbuhan merupakan sumber bahan aktif yang dapat digunakan sebagai komponen obat paling banyak digunakan dan memainkan peran penting dalam pengobatan atau pencegahan penyakit manusia (Alnajar et al 2012). Hingga saat ini pencaharian senyawa biokatif dari tumbuhan terus dilakukan termasuk Melastoma malabathricum. Melastoma malabathricum atau yang dikenal juga sebagai sendudukan berhabitus perdu dan muda ditemukan di Indonesia terutama pada lahan suksesi. Tumbuhan ini memiliki mahkota bunga yang indah bewarna ungu sehingga sering digunakan sebagai tanaman hias. Buahnya juga sering dimakan terutama bagi masyarakat yang tinggal di pedesaan. Berdasarkan survei yang saya lakukan di beberapa pasar tradisional di Jawa Barat terutama di Kota Bekasi, bunga khususnya benang sari telah lama diperjual-belikan untuk digunakan sebagai bahan sayuran. Selain digunakan sebagai bahan pangan, ternyata berbagai laporan penelitian menyatakan bahwa $M$. malabathricum banyak digunakan sebagai bahan obat tradisional. Berbagai etnis lokal di Indonesia memanfaatkan M. malabathricum sebagai obat tradisional. Pedagang tumbuhan obat di Pasar tradisional Kabanjahe, Sumatera Utara memanfaatkan daun $M$. malabathricum untuk mengatasi diare, patah tulang (Silalahi et al (2015b), dan bahan sauna tradisional atau oukup (Silalahi et al 2015b; Silalahi dan Nisyawati 2019). Daun $M$. malabathricum oleh etnis Batak Simalungun di Sumatra Utara, dimanfaatkan untuk mengatasi gangguan saluran pencernaan dan luka (Silalahi et al 2015a). Suku Dayak Pesaguan di Kalimantan Barat, memanfaatkan $M$. malabathricum untuk mengatasi kejengkolan (keracunan karena makan jengkol), kejang, dan ayan (Due 2013), Dayak Iban memanfatkannya untuk mengatasi sakit perut dan sariawan (Pradityo et al 2016), sedangkan suku Anak Dalam di Jambi memanfaatkan untuk mengatasi diare (Siregar et al 2020). Selain masyarakat lokal di Indonesia, ternyata masyarakat lokal di Malaysia juga memanfaatkan M. malabathricum terutama untuk penyembuhan luka karena memiliki aktivitas antibakteri (Sunilson et al 2008). Penelitian bioaktivitas M. malabathricum telah banyak dilakukan, namun fokusnya berbeda-beda sehingga informasinya kurang konfrehensif. Zakaria et al (2006) menyatakan bahwa ekstrak kloroform daun M. malabathricum memiliki bioaktivitas sebagai antinociceptive, antiinflamantori dan antipiretik (Zakaria et al 2006a dan 2016b), sedangkan Joffry et al. (2012) melaporkan bioaktivitasnya sebagai antinociceptive, antiinflamasi, penyembuhan luka, antidiare, sitotoksik, dan antioksidan. Pemanfaatan tumbuhan sebagai obat tradisional berhubungan dengan senyawa bioaktifnya. Sebagai contoh bioaktivitas sebagai antioksidan banyak dihubungkan dengan kandungan senyawa fenolik (Zakaria et al 2011). Untuk pemanfaatan tumbuhan sebagai obat tradisonal maupun untuk tujuan pengembangan menjadi obat terstandart maupun fitofarmaka dibutuhkan penelitian yang mendalam. Pemanfaatan bahan alam termasuk M. malabathricum sebagai obat tradisional dianggap lebih aman dengan efek samping yang relatif rendah, walaupun demikian perlu pengetahuan dan pemahaman tentang bioaktivitasnya sehingga pemanfaatannya dapat dikembangkan dan efek samping dapat diminimalisasi. Kajian bertujuan menjelaskan hubungan pemanfaatan dan bioaktivitas M. malabathricum sehingga pemanfaatannya oleh masyarakat dapat dikembangkan dan efek sampingnya dapat diminimalisasi.

\section{Perumusan Masalah}

Pemanfaatan bahan alam termasuk M. malabathricum sebagai obat tradisional dianggap lebih aman dengan efek samping yang relatif rendah, walaupun demikian perlu pengetahuan dan pemahaman tentang bioaktivitasnya sehingga pemanfaatannya dapat dikembangkan dan efek samping dapat diminimalisasi 


\section{Tujuan Penelitian}

Kajian bertujuan menjelaskan hubungan pemanfaatan dan bioaktivitas M. malabathricum sehingga pemanfaatannya oleh masyarakat dapat dikembangkan dan efek sampingnya dapat diminimalisasi.

\section{Manfaat Penelitian}

Bagi masyarakat sebagai informasi yang konfrehensif mengenai pemanfaatan dan bioaktivitas $M$. malabathricum. Bagi peneliti sebagai informasi untuk pengenbangan obat tradisional menjadi obat herbal terstandart atau fitofarmaka.

\section{METODE PENELITIAN}

Metode yang digunakan dalam penulisan artikel adalah metode studi literature yang didasarkan terbit secara online terutama di google dan google scholar. Beberapa kata kunci yang digunakan anatara lain: Melastoma malabathricum, uses of Melastoma malabatricum, dan bioactivities $M$. malabathricum. Informasi yang diperoleh disintesakan sehingga dapat menjelaskan manfaat dan bioaktivitas M. Malabathricum.

\section{HASIL DAN PEMBAHASAN \\ Botani Melastoma malabathricum}

Melastoma malabathricum merupakan salah satu species dalam famili Melastomaceae yang telah lama digunakan masayarakat lokal Indonesia maupun negara lain sebagai bahan pangan, pewarna dan juga sebagai bahan Obat. Melastomataceae memiliki sekitar 200 hingga 220 genera dengan jumlah species diperkirakan sekitar memiliki sekitar 4.500- 5300 spesies dan pada dasarnya terbatas pada daerah tropis dan subtropics (Nayar 1972; Abdulla dan Yong 2007). Di Indo-Malesia famili Melastomaceae diperkirakan ditemukan terdiri dari 64 genera dan sekitar 1300 spesies (Nayar 1972). Genus Melastoma merupakan salah satu genus terbesar dalam family Melastomaceae. Di wilayah Asia Tenggara, genus Melastoma terdiri dari 22 spesies. Melastoma malabatrichum memiliki dua sub spesies dan tiga varietas yang diklasifikasikan berdasarkan warna dari kelopak bunga yaitu magenta pink muda, ungu gelap magenta dan putih (Rajenderan 2010). Melastoma malabatrichum memiliki perawakan berupa semak atau pohon kecil, hingga $5 \mathrm{~m}$ tingginya. Kulit kayu berwarna coklat. Batang yang masih muda berbentuk menyegiempat dan terutupi oleh sisik, seiring dengan usia, bentuk batang mengalami perubahan menjadi gilig. Daun: Tangkai hingga 2 $\mathrm{cm}$ panjangnya. Helaian jorong - lanset, panjang $6-15 \mathrm{~cm}$ dan lebar $2-6.5 \mathrm{~cm}$. Pangkal daun membundar hingga runcing dan meruncing pada ujungnya (Gambar 1A). Permukaan atas daun tertutupi oleh rambut dan permukaan bawah ditutupi oleh sisik dan rambut. Tulang daun utama bervariasi antara 5 atau 7. Bunga: Perbungaan berbatas, tergabung sebagai malai ujung cabang, bunga 3 - 12 kuntum, jarang bunga muncul secara soliter. Jumlah bagian bunga umumnya 5, namun ditemukan juga bagian bunga dengan kelipatan 6,7 atau 8 (Gambar 1B). Tabung kelopak berbentuk seperti lonceng dan tertutupi oleh sisik yang merebah atau sedikit menyebar. Mahkota bunga ungu, jarang putih, bundar telur sungsang. Benang sari dapat dimorfik atau monomorfik. Bakal buah lebih pendek dari tabung kelopak dan di ujungnya terdapat rambut berwarna keemasan. Buah dan Biji: Buah kapsul yang mendaging, bulat, panjang 6,5 - 11,5 mm dan lebar 5 - 10,5 mm, pecah saat masak. Pulp berwarna biru tua (Gambar 1C). Biji berwarna jingga (Silalahi dan Mustaqim 2020 in press). 

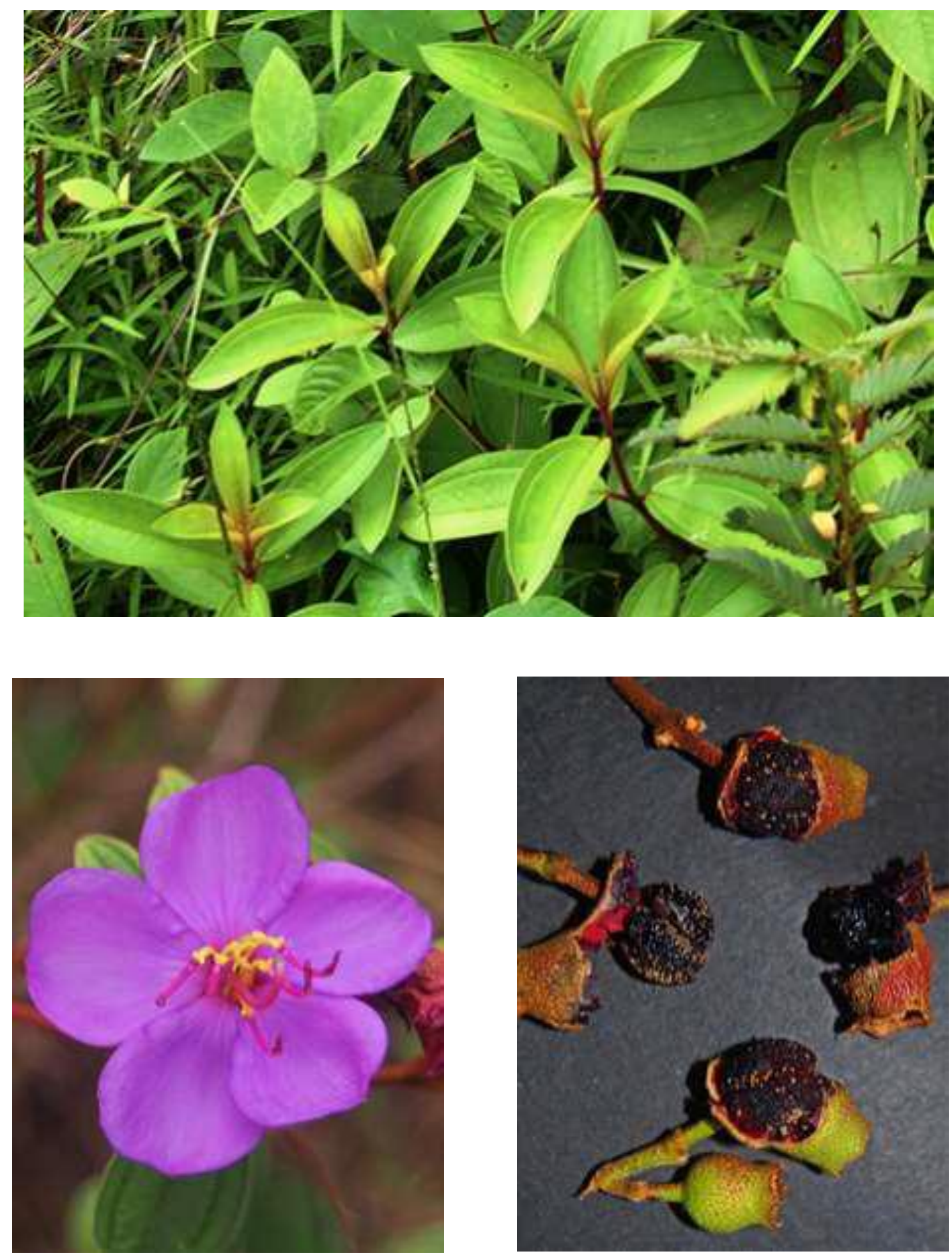

Gambar Melastoma malabathricum. A. Ranting dengan daun; B. Bunga; C. Buah yang sudah tua pecah.

\section{Manfaat Dan Bioaktivitas}

Masyarakat lokal di Indonesia dan di berbagai negara lain telah lama memanfaatkan $M$. malabathricum sebagai obat tradisional untuk mengatasi luka, diare, patah tulang, gangguan saluran pencernaan, mengatasi keracunan, diabetes mellitus dan bahan sauna tradisional. Berikut ini akan dijelaskan lebih lanjut mengenai bioaktivitas M. malabathricum. 


\section{Antikanker}

Penggunaan obat herbal sebagai pelengkap dan pengobatan alternatif untuk perawatan pasien kanker atau penyakit kronis lainnya telah lama diakui (Zakaria et al 2011). Tumbuhan yang digunakan sebagai anti kanker merupakan tumbuhan yang menghasilkan senyawa yang mampu menginduksi sel mengalami apostosis, menghambat pertumbuhan sel, atau mengakibatkan kematian sel-sel kanker, namun tidak merusak sel normal. Kemampuan daun M. malabathricum sebagai anti kanker sangat dipengaruhi oleh jenis senyawa yang digunakan untuk ekstraksi dan organ yang digunakan. Ekstrak n-heksana, kloroform dan metanol dari daun, batang dan bunga $M$. malabathricum dengan konsentrasi 100; 25; 12,5; dan $6,25 \mu \mathrm{g} / \mathrm{mg}$ memiliki aktivitas melawan line sel kanker manusia (MCF-7) secara in vitro. Ekstrak metanol daun $M$. malabathricum menunujukkan anti kanker yang signifikan dengan nilai IC50 sebesar $7,14 \mu \mathrm{g} / \mathrm{mg}$ sedangkan ekstrak metanol dan klorofrom bunga menunjukkan aktivitas sedang terhadap MCF-7 sel kanker dengan nilai IC50 sebesar 33,63 $\mu \mathrm{g} / \mathrm{mg}$ dan $45,76 \mu \mathrm{g} / \mathrm{mg}$ secara berurutan setelah 72 jam perlakuan (Roslen et al 2014). Ekstrak air daun M. malabathricum menghambat proliferasi line sel Caov-3 dan HL-60, sedangkan ekstrak kloroform memiliki anti proliferative terhadap line sel Caov-3, HL-60, dan CEM-SS. Ekstrak metanol M. malabathricum antiproliferative melawan line sel MCF7, HeLa, Caov-3, HL-60, CEM-SS, MDA-MB-231. Semua ekstrak tidak menghambat proliferasisel 3T3, sehingga bersifat non sitotoksik (Zakaria et al 2011). Naringenin and kaempferol-3-O-(200,600-di-O-p-trans-coumaroyl) glucoside menghambat proliferation sel MCF7 dengan nilai IC50 0.28 $\mu \mathrm{M}$ dan $1.3 \mu \mathrm{M}$, secara berurutan (Susanti et al 2007).

\section{Hepatoprotektif}

Senyawa hepaprotektif merupakan senyawa yang mampu mengembalikan atau menjaga fungsi hati dari senyawa toksik. Pemberian ekstrak methanol daun M. malabathricum (50, 250 , atau $500 \mathrm{mg} / \mathrm{kg}$ ) selama 7 hari menunjukkan aktivitas hepatoprotektif yang signifikan $(\mathrm{p}<0,05)$ terhadap kedua induser, seperti yang ditunjukkan oleh peningkatan dalam tes fungsi hati. Ekstrak methanol daun M. malabathricum memiliki aktivitas hepatoprotektif, yang dikaitkan dengan kandungan fitokimia dan aktivitas antioksidan (Kamisan et al 2013).

\section{Antikolesterol}

Hiperlipidemia merupakan suatu kondisi terjadinya peningkatan kadar lemak dalam darah karena konsumsi lemak secara berlebihan, sehingga asupan dan perombakan lemak tidak seimbang (Arief et al 2012). Ektrak etanol daun M. malabathricum memiliki aktivitas antidiabetik dan anti hiperlipidaemik yang diberikan pada tikus yang diinduksi dengan aloksan. Tikus albino yang telah diberikan dengan alloksan monohydrate $(150 \mathrm{mg} / \mathrm{kg}$ i.p) kemudian diberikan dengan ektrak alcohol M. malabathricum dengan dosisi 150 dan 300 $\mathrm{mg} / \mathrm{kg}$ berat badan yang diberikan selama 14 hari. Ekstrak alcohol daun M. malabathricum hingga $2000 \mathrm{mg} / \mathrm{kg}$ bb tikus tidak bersifat toksik. Peningkatan berat badan, penurunan glukosa darah, glikosilat haemoglobin dan parameter biokimia lainnya diamati pada tikus diabetes yang diberi ekstrak alkohol daun $M$. malabathricum dibandingkan dengan tikus kontrol (Balamurugan et al 2014). Melastoma malabathricum memiliki kandungan metabolit sekunder berupa flavonoid, saponin, dan tannin, yang diduga mempunyai efek menurunkan lipid darah. Ekstrak etanol bunga M. malabathricum menurunkan kadar kolesterol total dan trigliserida pada tikus putih jantan hiperlipidemia yang diinduksi propiltiourasil. Terdapat perbedaan bermakna pada kadar trigliserida antara kontrol negatif dan kontrol positif dengan kelompok yang diberikan ekstrak etanol bunga M. malabathricum dengan dosis $0,01 \mathrm{mg} / \mathrm{g}$ BB. Ekstrak etanol bunga M. malabathricum dengan dosis $0,1 \mathrm{mg} / \mathrm{g}$ BB dan $1 \mathrm{mg} / \mathrm{g}$ BB memiliki efek yang sama dengan simvastatin dalam menurunkan kadar kolesterol total dan trigliserida, sedangkan ekstrak etanol dengan dosis $0,01 \mathrm{mg} / \mathrm{g}$ BB hanya 
memiliki efek yang sama dengan simvastatin dalam menurunkan kolesterol total (Arief et al 2012).

\section{Antimikroba}

Ekstrak metanol dari $M$. malabathricum menghasilkan respons yang signifikan pada kedua jenis luka yang diuji luka eksisi dan luka sayatan sebanding dengan obat standar, nitrofurazone, dalam hal kemampuan kontraksi luka, waktu penutupan luka, kekuatan tarik dan regenerasi jaringan di lokasi luka. Ekstrak etanol M. malabathricum menghambat pertumbuhan isolat klinis luka Staphylococcus aureus dan Pseudomonas aeruginosa dengan minimal inhibition concentration (MIC) mulai dari 3,0 mg / ml untuk 3 dari 4 strain klinis S. aureus hingga $8,0 \mathrm{mg} / \mathrm{ml}$ untuk semua 3 klinis strain $P$. aeruginosa yang diuji (Sunilson et al 2008). Berbagai peneliti telah melaporkan mampu menghambat pertumbuhan bakteri seperti: Staphylococcus aureus, Escherichia coli (Choudhury et al 2011; Omar et al. 2013; Alnajar et al 2012), Streptococcus sp. (Choudhury et al 2011), Listeria monocytogenes, Salmonella typhimurium (Omar et al. 2013), Streptococcus agalactiae dan Klebsilla pneumonia (Alnajar et al 2012). Selain menghambat pertumbuhan bakteri, ekstrak $M$. malabathricum menghambat pertumbuhan fungi yaitu Trichophyton mentagrophyte dan Candida albicans (Gholib 2009). Bioaktivitas M. malabathricum sebagai anti mikroba dipengaruhi oleh organ (bagian) yang digunakan, senyawa yang digunakan untuk ekstraksi, dan konsentrasi yang digunakan. Ekstrak methanol dan aseton daun M. malabathricum memiliki aktivitas antibakteri secara signifikan terhadap Staphylococcus aureus, Streptococcus sp. dan Escherichia coli dengan metode difusi cakram (Choudhury et al 2011). Ekstrak metanol dan aseton daun M. malabathricum menghasilkan zona penghambatan yang signifikan terhadap Staphylococcus aureus $(13,06 \mathrm{~mm})$ (Choudhury et al 2011). Ekstrak kasar bunga dan buah M. malabathricum menghambat pertumbuhan bakteri Listeria monocytogenes, Staphylococcus aureus, Escherichia coli, dan Salmonella typhimurium menggunakan metode difusi disk (Omar et al 2013). Ekstrak etanol daun $M$. malabathricum memiliki aktivitas anti fungi pada Trichophyton mentagrophyte dan Candida albicans dilakukan dengan metode difusi dan dilusi (Gholib 2009).

\section{Antioksidan}

Ekstrak daun dan bunga $M$. malabathricum telah banyak dilaporkan sebagai antioksidan. Bunga $M$. malabathricum yang diekstraksi dengan etanol kemudian diasamkan dengan asam sitrat 3\% atau $\mathrm{HCl} 1 \%$ menghasilkan ekstrak dengan kadar total antosianin 38,38 mg/100 gr $\mathrm{db}$, kadar total fenol $127,73 \mathrm{mg} / 100 \mathrm{gr}$ db memiliki aktivitas penangkapan radikal bebas dengan nilai IC50 865,50 ppm (Kristiana et al 2012). Total konten fenolik yang dicatat untuk ekstrak air, metanol, dan kloroform daun M. malabathricum sebesar 3344,2 $\pm 19,1 ; 3055,1 \pm$ 8,7; dan 92,5 $\pm 7,3 \mathrm{mg} / 100 \mathrm{~g}$ asam galat secara berurutan (Zakaria et al 2011). Ekstrak etanol dan air daun $M$. malabathricum menunjukkan kemampuan untuk memulung radikal bebas DPPH nilai IC50 11,599 \pm 0,84 dan 62,657 \pm 0,78 secara berurutan (Alnajar et al 2012). Bioaktivitas $M$. malabathricum sebagai antioksidan banyak dihubungkan dengan kandungan senyawa flavonoidnya dan berbanding lurus dengan kandungan senyawa flavonoidnya. Ekstrak n-heksana daun $M$. malabathricum menghasilkan $\alpha$-amyrin, patriscabatrine dan auranamide, ekstrak etil asetat daun $M$. malabathricum memberikan quercetin dan quercitrin, dan ekstrak metanol memberi quercitrin dan kaempferol-3-O- (2 ", 6" -di-O-ptrans-coumaroyl) glukosida (Susanti et al 2008). Ekstrak etil asetat bunga M. malabathricum menghasilkan tiga senyawa, diidentifikasi sebagai naringenin, kaempferol dan kaempferol3-O-D-glukosida, dan methanol ekstrak memberikan kaempferol-3-O- (200.600-di-O-ptrans-coumaroyl) glukosida dan kaempferol-3-O-D-glukosida. $\mathrm{N}$ aringenin, kaempferol, kaempferol-3-O-D-glukosida, kaempferol-3-O- (200.600-di-O-p-trans-coumaroyl) 
glukosida, etil asetat dan ekstrak metanol bunga $M$. malabathricum memiliki aktivitas pemulung radikal DDHP dengan nilai IC50 0,52 mM, 81,5 $\mu \mathrm{M}, 1,07 \mathrm{mM}, 35,8 \mu \mathrm{M}, 7,21 \mu \mathrm{g}$ $/ \mathrm{ml}$ dan $6,59 \mu \mathrm{g} / \mathrm{ml}$ secara berurutan (Susanti et al 2007).

\section{Antiulkus}

Ulkus (ulcer) merupakan suatu kondisi terjadinya luka di dalam tubuh seperti ulkus kulit dan ulkus lambung. Berbagai peneliti melaporkan bioaktivitas M. malabathricum sebagai untuk mengatasi ulkus terutama ulkus lambung seperti Zabidi et al (2012), Suhaimy et al (2017) dan Halim et al (2017), sehingga daun M. malabathricum memiliki aktivitas gastroprotektif (Suhaimy et al 2017). Di laboratorium, untuk menginduksi ulkus lambung dapat digunakan etanl dan indometasin (Zabidi et al 2012). Zabidi et al (2012) melaporkan bahwa tikus yang diberi ekstrak metanol daun M. malabathricum dengan konsentrasi 50,250 dan $500 \mathrm{mg} / \mathrm{kg}$ kemudian diikuti induksi ulkus lambung dengan menggunakan etanol menunjukkan aktivitas antiulcer yang signifikan, namun tidak untuk ulkus yang diinduksi indometasin (Zabidi et al 2012). Aktivitas daun M. malabathricum sebagai gastroprotektif dipengaruhi oleh polaritas ekstraksi. Partisi ekstrak petroleum eter, etil asetat, dan air daun $M$. malabathricum memiliki aktivitas gastroproteksi yang signifikan, namun partisi dengan menggunakan etil asetat paling efektif (Suhaimy et al 2017). Ekstrak etil asetat daun $M$. malabathricum secara signifikan mengurangi volume dan keasaman melalui peningkatan $\mathrm{pH}$ lambung dan meningkatkan sekresi lendir dinding lambung dan meningkatkan aktivitas enzimatik dan nonenzimatik dari jaringan lambung (Suhaimy et al 2017). Bioaktivitas daun M. malabathricum sebagai gastroprotektif diduga berhubungan dengan kandungan flavonoidnya (Suhaimy et al 2017; Halim et al 2017). Halim et al (2017) menyatakan bioaktivitas $M$. malabathricum sebagai gastroprotektif lebih tinggi ketika diberikan bersamaan dengan ekstrak Muntingia calabura (Halim et al 2017).

\section{Analgesik}

Nyeri atau sering juga dikenal sebagai rasa sakit merupakan bentuk respon langsung tubuh terhadap kerusakan pada jaringan tubuh yang dapat berupa luka, infeksi atau penyakit lainnya yang memicu pelepasan mediator nyeri seperti histamin, bradikinin, leukotrien, dan prostaglandin. Senyawa yang berfungsi mengurangi rasa nyeri atau sakit dikenal dengan analgesik. Antinosiseptik merupakan uji yang digunakan untuk mengetahui potensi suatu senyawa sebagai analgesik sedangkan rasa nyeri diinduksi dengan asam asetat dengan mempengaruhi aktivitas system saraf pusa dan saraf perifer (Sulaiman et al 2004). Ekstrak M. malabathricum (30-300 mg/kg) menghambat aktivitas menggeliat pada tikus yang diinduksi asam asetat ED50 100 (78-160) mg / kg i.p. Antagonis reseptor opioid nonselektif, nalokson memblokir efek antinociceptive dari ekstrak M. malabathricum (Sulaiman et al 2004). Ekstrak kloroform daun M. malabathricum yang dilarutkan dengan dimethyl sulfoxide dengan dosis 20, 100 dan 200\% yang diberikan pada subcutaneous 30 menit sebelum sebelum diberikan menunjukkan aktivitas antinociceptive dan anti inflamantory yang signifikan (Zakaria et al 2006a).

\section{Antidiabetes Mellitus}

Tumbuhan yang digunakan sebagai anti diabetes mellitus merupakan tumbuhan yang menghasilkan senyawa yang mampu menghambat penyerapan glukosa ke dalam darah atau mampu memperlambat pemecahan karbohidrat. Tikus diabetes diinduksi dengan injeksi intra-peritoneal streptozotocin $(55 \mathrm{mg} / \mathrm{kg})$ kemudian diberi ekstrak metanol $M$. malabathricum tidak menunjukkan toksisitas akut hingga dosis $2000 \mathrm{mg} / \mathrm{kg}$ dan memperlihatkan pemanfaatan glukosa yang lebih baik dalam uji toleransi glukosa oral. Pemberian secara oral ekstrak daun M. malabathricum dari dosis yang berbeda (100, 250, 
$500 \mathrm{mg} / \mathrm{kg}$, p.o.) menurunkan kadar glukosa serum, hemoglobin terglikasi, glukosa-6fosfatase, fruktosa-1-6-bifosfat dan meningkatkan kadar insulin plasma, hexokinase. Pemberian ekstrak daun $M$. malabathricum menurunkan malondialdehida hati tetapi meningkatkan superoksida dismutase, katalase dan glutation peroksidase. Tikus diabetes diinduksi dengan streptozotocin kemudian diobati dengan ekatrak daun M. malabathricum dan glibenclamide $(10 \mathrm{mg} / \mathrm{kg}$, p.o.) secara signifikan meningkatkan berat badan (Kumar et al 2013)

\section{KESIMPULAN}

1. Secara etnobotani M. malabathricum digunakan untuk untuk mengatasi diare, patah tulang, luka, mengatasi kejengkolan, kejang, ayan dan sariawan.

2. Bioaktivitas M. malabatrhricum anatara lain anti kanker, hepatoprotektif, antikolesterol, antimikroba, antioksidan, antiulkus, analgesik dan antidiabetes mellitus.

3. Bioaktivitas $M$. malabathricum berhubungan dengan kandungan senyawa metabolit sekundernya seperti flavonoid dan phenolic.

\section{DAFTAR PUSTAKA}

Abdullah, J.O. and Yong, W.T.L. 2007. Melastomaceae: Inherent economical values substantianting potentia transgenic studies in the family. Transgenic Plant Journal 1(1): 237-243.

Alnajar, Z.A.A., Abdulla, M.A., Ali, H.M., Alshawsh, M.A. and Hadi, A.H.A. 2012. Acute toxicity evaluation, antibacterial, antioxidant and immunomodulatory effects of Melastoma malabathricum. Molecules 2012, 17, 3547-3559; doi:10.3390/molecules 17033547.

Arief, M.I., Novriansyah, R., Budianto, I.T. and Harmaji, M.B. 2012. Potensi bunga karamunting (Melastoma malabathricum L.) terhadap kadar kolesterol total dan trigliserida pada tikus putih jantan hiperlipidemia yang diinduksi propiltiourasil. Prestasi 1(2): 118-125.

Balamurugan, K., Nisthanthini, A. and Mohan, V.R. 2014. Antidiabetic and antihyperlipidemic activity of ethanol extract of Melastoma malabathricum Linn. Leaf in alloxan induced diabetic rat. Asian Pac J Trop Biomed 4(suppl1): s442-s448.

Choudhury, M.D., Nath, D. and Talukdar, A.D. 2011. Antimicrobial activity of Melastoma malabathricum L. Biological and Environmental Sciences 7(1): 76-78.

Due, F. 2013. Etnobotani tumbuhan obat Suku Dayak Pesaguan dan implementasinya dalam pembuatan flash card biodiversitas. (Skripsi). Program Studi Pendidikan Biologi Jurusan PMIPA, Fakultas Keguruan dan Ilmu Pendidikan, Universitas Tanjungpura, Pontianak.

Gholib, D. 2009. Uji daya hambat daun senggani (melastoma malabathricum 1.) terhadap Trichophyton mentagrophytees dan Candida albicans. Berita Biologi 9(5): 523-527

Halim, S.Z., Zakaria, Z.A., Omar, M.H., Mohtarrudin, N., Wahab, I.R.A., and Abdullah, M.N.H. 2017. Synergistic gastroprotective activity of methanolic extract of a mixture of Melastoma malabathricum and Muntingia calabura leaves in rats. BMC Complementary and Alternative Medicine 17:488. DOI 10.1186/s12906-017-1992-9.

Kamisan, F.H., Yahya, F., Ismail, N.A., Din, S.S., Mamat, S.S., Zabidi, Z., Zainulddin, W.N.W., Mohtarrudin, N., Husain, H., Ahmad, Z., and Zakaria, Z.A. 2013. Hepatoprotective activity of methanol extract of Melastoma malabathricum leaf in rats. J Acupunct Meridian Stud 6(1): 52-55. 
Kristiana, H.D., Ariviani, S. and Khasanah, L.U. 2012. Ekstraksi pigmen antosianin buah senggani (Melastoma malabathricum Auct. Non Linn) dengan variasi jenis pelarut. Jurnal Teknosains Pangan 1(1): 105-109.

Nayar, M.P. 1972. Centres of development and patterns of distribution of the family Melastomataceae nn Indo-Malesia. Bult. Bot. Surv. India 14: 1-12.

Pradityo, T., Santoso N. and Zuhud, E.A.M. 2016. Etnobotani di kebun Tembawang Suku Dayak Iban, Desa Sungai Mawang, Kalimantan Barat. Media Konservasi 21(2): 183198.

Rahman, M.R.A., Razak, F.A. and Bakri, M.M. 2014. Evaluation of wound closure activity of Nigella sativa, Melastoma malabathricum, Pluchea indica, and Piper sarmentosum extracts on scratched monolayer of human gingival fibroblasts. Hindawi Publishing Corporation. Evidence-Based Complementary and Alternative Medicine Volume 2014, Article ID 190342, 9 pages http://dx.doi.org/10.1155/2014/190342

Rajenderan, M.T. 2010. Ethnomedicinal uses and antimicrobial properties of Melastoma malabathricum. Segi Review 3: 34-44.

Roslen, N.A., Alewi, N.A.M., Ahamada, H. and Rasad, M.S.B.A. 2014. Cytotoxity screening of Melastoma malabathricum extracts on human breast cancer cell lines in vitro. Asian Pac J Trop Biomed 4(7): 545-548.

Silalahi, M., Nisyawati, Walujo, E.B. and Supriatna, J. 2015a.Local knowledge of medicinal plants in sub-ethnic Batak Simalungun of North Sumatra, Indonesia. Biodiversitas 16(1): 44-54.

Silalahi M, Nisyawati, Walujo, E.B., Supriatna, J., \& Mangunwardoyo, W. 2015b. The local knowledge of medicinal plants trader and diversity of medicinal plants in the Kabanjahe traditional market, North Sumatra, Indonesia. Journal of Ethnopharmacology 175: 432-443.

Silalahi, M., Nisyawati, \& Pandiangan, D. 2019. Medicinal plants used by the Batak Toba Tribe in Peadundung Village, North Sumatra, Indonesia. Biodiversitas 20(2): 510-525.

Silalahi, M. and Nisyawati. 2019. An ethnobotanical study of traditional steam-bathing by the Batak people of North Sumatra, Indonesia. Pacific Conservation Biology 25 (3): 266-282.

Silalahi, M. dan Mustaqim, W.A. 2020. Tumbuhan Berbiji Di Jakarta Jilid 2: 100 Jenis-Jenis Non Pohon Terpilih. UKI Press, Jakarta.

Siregar, M.R.A., Perawati, S. and Andriani, L. 2020. Etnofarmakognosi pada Suku Anak Dalam di Desa Hajran Kecamatan Bathin XXIV Kabupaten Batanghari. Journal of Healthcare Technology and Medicine 6(1): 225-230.

Suhaimy, N.W.I., Azmi, A.K.N., Mohtarrudin, N., Omar, M.H., Tohid, S.F.M., Cheema, M.S., Teh, L.K., Salleh, M.Z. and Zakaria, Z.A. 2017. Semipurified ethyl acetate partition of methanolic extract of Melastoma malabathricum leaves exerts gastroprotective activity partly via its antioxidant-antisecretory-anti-inflammatory action and synergistic action of several flavonoid-based compounds. Hindawi Oxidative Medicine and Cellular Longevity Volume 2017, Article ID 6542631, 14 pages https://doi.org/10.1155/2017/6542631.

Sulaiman, M.R., Somchit, M.N., Israf, D.A., Ahmad, Z. and Moin, S. 2004. Antinociceptive effect of Melastoma malabathricum ethanolic extract in mice. Fitoterapia 75: 667-672.

Sunilson, A.J.J., James, J., Thomas, J., Jayaraj, P., Varatharajan, R. and Muthappan, M. 2008. Antibacterial and wound healing activities of Melastoma malabathricum. Linn. Afr. J. Infect. Dis. 2(2): 68-73.

Susanti D., Sirat, H.M., Ahmad, F., Ali, R.M., Aimi, N., and Kitajima, M. 2007. Antioxidant and cytotoxic flavonoids from the flowers of Melastoma malabathricum L. Food Chemistry 103:710-716. 
Zabidi, Z., Zainulddin W.N.W, Mamat, S.S., Din, S.S., Kamisan, F.H., Yahya, F., Ismail, N.A., Rodzi, R., Hassan, H., Mohtarrudin, N., Somchit, M.N. and Zakaria, Z.A. 2012. Antiulcer activity of methanol extract of Melastoma malabathricum leaves in rats. Med Princ Pract 21: 501-503.

Zakaria, Z.A., Rofiee, M.S., Mohamed, A.M., Teh, L.K. and Salleh, M.Z. 2011. In vitro antiproliferative and antioxidant activities and total phenolic contents of the extracts of melastoma malabathricum leaves. J Acupunct Meridian Stud 4(4): 248-256.

Zakaria, Z.A., Nor, R.N.S.R.M., Sulaiman, M.R., Ghani, Z.D.F.A., Kumar, G.H. and Fatimah, C.A. 2006a. Antibociceptive and anti-inflammantory properties of Melastoma malbathricum leaves chloroform extract in experiental animal. Journal of Pharmacology and Toxycology 1(4): 337-344.

Zakaria Z.A., Nor, R.N.S.R.M, Kumar, G.H., Ghani Z.D.F.A., Sulaiman, M.R., Devi, G.R., Jais, A.M.M., Somchit, M.N. and Fatimah, C.A. 2006b. Antinociceptive, antiinflammatory and antipyretic properties of Melastoma malabathricum leaves aqueous extract in experimental animals. Can. J. Physiol. Pharmacol. 84: 1291-1299.

\begin{tabular}{|l|l|l|l|}
\hline Accepted Date & Revised Date & Decided Date & Accepted to Publish \\
\hline 15 Agustus 2020 & 16 Agustus 2020 & 18 Agustus 2020 & Ya \\
\hline
\end{tabular}

